Scientia Militaria vol 40, no 3, 2012, pp.318-353. doi: 10.5787/40-3-1039

\title{
The Lessons of the Border War
}

\author{
Leopold Scholtz
}

\begin{abstract}
A quarter of a century after the end of the Border War, the SANDF's institutional memory of the conflict is slowly fading. And yet there are several lessons emanating from the war, which are relevant to the Defence Force. This article attempts to map out some of these lessons. These lessons are as follows. (1) The need for combined arms units such as 61 Mechanised Battalion Group and 4 SAI, being a mix of mechanised infantry, armoured cars, tanks, artillery and support troops on battalion level. (2) The importance of logistic support, something that was not always sufficient during Operations Moduler, Hooper and Packer in 1987-1988. (3) Reserve force units must be adequately retrained when utilised in operations. (4) During the war, there was a gap in the Army's anti-aircraft capability. This gap has not been rectified since. (5) In order to be able to command the air above a battlefield, an aerial refuelling capability for the SAAF is essential. (6) The Army needs a proper air assault and maritime amphibious capability. (7) When deciding to engage in a warlike operation, avoid the incremental commitment, which characterised both Operation Savannah in 1975 and Moduler in 1988. (8) While the field units fight on the battlefield, do not micromanage things from above. As long as the units keep within the political and operational parameters set by the politicians and generals, let the field commanders exercise their own initiative. (9) Make a renewed study of the Army's mobile warfare doctrine of the seventies and eighties, as developed by officers such as Major General Roland de Vries. (10) Lastly,
\end{abstract}

\footnotetext{
Dr Leopold Scholtz is a research fellow in History at the University of Stellenbosch and Media 24's correspondent in Europe. He has recently completed a manuscript about the history of the Border War. He also held the rank of Captain (Infantry) in the Reserve Force of the South African Army.
} 
see to it that officers are not just trained, but intellectually educated about war as well.

Key words: Border War, SADF, SANDF, combined arms, reserve force, Operation Savannah, Operation Moduler, mobile warfare doctrine, military education

\section{Introduction}

At the time of writing, the Border War has been over for 24 years. Some of the South African Defence Force (SADF) officers and non-commissioned officers (NCOs) who fought in the war still wear uniform in the South African National Defence Force (SANDF), but it is safe to say that the majority have either taken early retirement packages during the nineties or retired at the age of 65 . Already the memories of the Border War are fading - an unavoidable by-product of the passage of time and increasing age.

At the same time, it is necessary to keep the memory of the conflict alive - not to score political points or to re-fight the war with words, but from a professional point of view. The Border War consumed a large part of the SADF's resources for about a quarter of a century, and in the process, a large body of experience and know-how was built up. The SADF had a formidable reputation, especially as a ferocious tactical force. It also made mistakes, especially on the military-strategic level. It would be a pity if these insights were allowed to wither away. After all, although South Africa's security-strategic position has changed drastically in the years since the end of the war in 1989, the country still needs a competent defence force capable of fighting a war, even if that war would differ in many respects from the Border War. Learning and remembering the lessons of the Border War - the successes and failures of the SADF - could only benefit the SANDF. The SADF had a healthy practice of examining each operation afterwards in order to learn from the experience. Often, a staff officer was appointed to write a history of the specific operation. Although criticism of the SADF leadership was muted (understandably, nobody wanted to jeopardise his or her career), it does shimmer through if one knows what to look for. 
An additional perspective worth mentioning is that the institutional memory of the SADF/SANDF is formed largely by the Border War, and not so much by the SADF's involvement in township unrest in the eighties in support of the Police.

The analysis in this article is based mostly on the insights I got while researching and writing a book about the Border War. ${ }^{1}$ A working knowledge of the war is presumed. I shall start with some tactical and operational lessons, and then work my way to the military-strategic level.

\section{Combined Arms Forces}

Traditionally, during the early 20th century, the battlefield arms of armies were divided into infantry, artillery, armour and the like. In the thirties, the Germans started mixing these corps on a divisional level. A typical panzer division would contain one or two tank multi-battalion regiments, an infantry brigade (mostly motorised, but in the elite divisions also mechanised), artillery and other support units. ${ }^{2}$ With this formidable weapon, the German army swept away everything before it in the first half of the Second World War. That Adolf Hitler overburdened his country by taking on too many enemies and thereby lost the war, was not the fault of the panzer divisions.

The German example was taken over by many armies during and after the Second World War, including the US Defence Force with its AirLand Battle and manoeuvre doctrine. The present tendency is to take the brigade as the standard balanced all-arms unit instead of the division, although divisions have not been abolished altogether. ${ }^{3}$ The US Army has even gone a step further. They have one (there were more, but these have not escaped the downsizing of the military) so-called "armoured cavalry regiment", in size about between a battalion/regiment and a brigade. In this unit, tanks and mechanised infantry (transported in Bradley infantry fighting vehicles) are integrated down to company level. This makes the 7th Armoured Cavalry Regiment one of the most flexible units in the American military. ${ }^{4}$

In principle, this unit transcends the traditional separation between armour and infantry. Rather, the unit may be described as a combined arms force. 
Building on the development of a new conventional warfare doctrine for the African battle space in the late sixties and early seventies, the South African Army also came up with a new type of unit. As an experiment, Battle Group Juliet was founded in the late seventies as an ad hoc conventional strike unit to be activated when the need arose. Juliet's first and only - operation was Operation Reindeer, the attack on the Swapo base of Chetequera and several smaller bases just north of the Angolan/Namibian border in May 1978. For this operation, Juliet consisted of Eland-90 armoured cars, mechanised infantry in Ratel-20s, and a battery of 140-mm G-2 guns. The attack was a success, and from the report by the Juliet commander, Commandant Frank Bestbier, it is clear that many lessons regarding the integrated utilisation of armour, mechanised infantry and artillery together with other support troops were learnt. ${ }^{5}$

From the beginning of 1979, Battle Group Juliet was converted into a permanent unit, 61 Mechanised Battalion Group (generally known as 61 Mech). It consisted of an armoured car squadron (Eland-90s, to start with), two mechanised infantry companies in Ratel-20s, an artillery battery (140mm G-2), and other support units. ${ }^{6}$ The Eland, though it was well liked by the troops, was not really up to the task:

- It had only four wheels, which made it less mobile than the Ratel;

- It had a flammable petrol engine, which made it vulnerable and necessitated a separate logistic apparatus alongside one for the supply of diesel;

- It could carry only an inadequate 20 rounds; and

- Its range was only $300 \mathrm{~km}$.

It was, therefore, progressively phased out and replaced by the Ratel90 , which, with its six wheels, a range of $800 \mathrm{~km}$ and 72 rounds of ammunition ${ }^{7}$ was well suited to mobile mechanised operations, and married up well with the Ratel-20s of the mechanised infantry.

During the eighties, the SADF utilised its armoured cars as ersatz tanks, pitching them with great success against Soviet T-34 tanks during Operation Protea (August 1981). But in December 1983 and January 1984, 
while Operation Askari was raging, the Ratels and Elands came up against the much-improved T-54/55s, against which they really struggled. They damaged five enemy tanks during the battle at Cuvelai on 4 January 1984, which were abandoned and taken over by the South Africans. ${ }^{8}$ This was remarkable, because the South African low-pressure gun, barring a lucky shot, did not have enough penetration power to knock out the T-54/55.

On Christmas, the OC 61 Mech, Commandant Ep van Lill, received a visit from the CSADF, General Constand Viljoen, at the front. Van Lill told the general that his men could not fight the well-armoured enemy tanks with the inadequate Ratel-90 and Eland-90. He wanted tanks. ${ }^{9}$ Besides, as Evert Jordaan has pointed out, this role into which the South African armoured cars were forced "contradicted South African Armoured Corps (SAAC) doctrine”, which was to fight tanks with tanks. ${ }^{10}$ Therefore, a squadron of Olifant tanks was moved, with their crews, from the School of Armour in Bloemfontein to 61 Mech's base at Omuthiya in the north of Namibia to constitute a permanent E Squadron. However, as Askari was the last of the big overt cross-border operations, the crews were taken back to Bloemfontein after a while, while the tanks were stored with $61 \mathrm{Mech}$. The tank men would come from time to time to exercise with the rest of 61 Mech. ${ }^{11}$

The war escalated again in September 1987, and 61 Mech and 32 Battalion were sent in to stave off an Angolan Army (Fapla) offensive against the rebel movement Unita. In the course of the fighting around the Lomba River, 61 Mech's Ratel-90s were once again used as if they were light tanks. Fapla was indeed stopped, and the unit's Ratel-90s had an extremely difficult job against the Angolan T-54/55s, and they (the Ratels) destroyed several with great difficulty. Not only did these unreasonable demands cause serviceability problems with the Ratels, but the morale of the Ratel crews also suffered when ordered to take on tanks in their vulnerable vehicles. ${ }^{12}$ Not surprisingly, they did not relish dying or being wounded unnecessarily.

When a counteroffensive was subsequently started, an Olifant tank squadron was brought in for the first time, attached to 4 SAI, a unit similar to 61 Mech. This squadron was manned by professionals and national servicemen from the School of Armour, and was in fact the only ready tank 
squadron in the entire Army. As was to be expected, after a while it was discovered that one squadron was not enough, and a second squadron was brought in, manned in rotation by citizen force (CF) members. Right at the end of the campaign, two new squadrons, also manned by CF soldiers, were committed. During this time, the two squadrons were alternatively attached to 61 Mech or 4 SAI as circumstances dictated. Subsequently, 61 Mech retained an Olifant squadron right to the end of the war. ${ }^{13}$ In a secret review of the war's lessons, it was also recommended that tanks be utilised to fight tanks, and that armoured cars were not sufficient. ${ }^{14}$

The point is that the South African Army had a very successful record, mixing armour, mechanised infantry and artillery in a single unit. Alas, 4 SAI has since been relegated to being a motorised infantry battalion while 61 Mech was foolishly disbanded (for political reasons?).

With the SANDF extensively involved in peace support operations in Africa, it has to retain its war-fighting capability, as it simply cannot be predicted whether such operations may deteriorate into something akin to war. One simply has to point to the DRC, the North and South Sudan or Somalia to understand that one has to be ready for a whole scala of alternatives. And in such a scenario, one or more combined arms units, similar to 61 Mech, may very well be necessary.

Therefore, Lesson 1 of the Border is: Reconstitute 61 Mech and 4 SAI as combined arms mechanised units. Combined with this is the urgent need for a replacement of the Olifant tank. One understands that the Army has only 24 upgraded Olifant Mk II tanks, while the rest are still the Mk 1s used in the Border War. Tanks are like a stick behind the door - even if they are never used, they give an army (and therefore the state) military credibility.

\section{Logistics}

Napoleon is reputed to have said, "An army marches on its stomach." Problem is, a modern army also needs ammunition, fuel, medical supplies, spare parts, etc. This was true of the Border War as well.

In general, the troops fighting the counter-insurgency war in the north of Namibia were well supplied. Most of the earlier cross-border operations 
in Angola were also short enough for the mechanised columns to carry enough ready supplies in their A-echelon convoys. At times, additional supplies had to be ferried to them, either by ground or by aircraft, but when a shortage of supplies occurred, it was incidental and mostly speedily resolved. Of course, the fact that the operations generally were no longer than three weeks helped.

Things changed during Operations Moduler, Hooper and Packer in 1987-1988. A brigade of about 3000 troops, with two mechanised battalion groups (including two tank squadrons), an infantry battalion (32 Battalion, half motorised, half mechanised), as well as an artillery regiment, fought a severe conventional war about 250 kilometres inside Angola, something which brought about an intense consumption of supplies. The supply chain began in Pretoria, and stretched all the way to Grootfontein in Namibia by road, by rail or by air. From there, most supplies were transported by the Air Force in their big C-130s or C-160s to the airstrip at Mavinga, deep inside Angola, but it all had to be done at night for fear of the Cuban MiGs prowling in the air. From Mavinga the supplies were loaded onto lorries, which had to bundu bash across the Lomba and Chambinga rivers to the forces north of the Chambinga. This was an extremely long chain, limited by the Air Force's inadequate airlift capacity and the perennial shortage of drivers. ${ }^{15}$

In a report about the lessons of the war, the chaotic state of the Army's logistic system was sharply criticised. According to the report, personnel and equipment were moved by air, rail and road between Pretoria, Grootfontein, Rundu and Mavinga, but there was no central controlling body. This meant that the loading of supplies were undertaken haphazardly, without the needs of the frontline troops being taken into account, with the result that urgent items often reached them late or not at all. ${ }^{16}$

No wonder then, that the South African forces fighting the Angolans in the vicinity of Cuito Cuanavale had to contend with a permanent and desperate shortage of just about anything - ammunition, spare parts for vehicles and weapons systems, uniforms and boots, medical supplies, food, etc. One reads repeatedly of tanks and artillery guns being unserviceable, and repaired just in time for the next battle thanks to the superhuman efforts of the technical staff, the badly appreciated "tiffies". Uniforms came apart. 
Troops went hungry and became ill with dysentery or "gyppo guts". Items, which had been ordered, did not arrive at all or weeks later. ${ }^{17}$

Some weeks later, the SADF had to decide how to respond to the Cuban threat materialising across the border in the province of Cunene. This was after President Fidel Castro had shipped his crack 50 Division to Angola and ordered them to advance southwards to the Namibian border. At first, there was an idea to launch a pre-emptive strike into Cunene and destroy the Cubans before they could get it into their heads to invade Namibia, but this was speedily changed into a defensive plan in order to lure the Cubans into a carefully planned killing field near Tsumeb, to destroy them and then to go over on the counteroffensive. For this purpose, the under-strength 10 Division was mobilised in Ovamboland. Several factors were responsible for the change, but one of them was the Logistic Service's unpleasant news that it could not support an offensive before December 1988 (and then only one with two brigades for just two months). ${ }^{18}$ This shows how the Army's supplies had been drained by the fighting at Cuito Cuanavale. Helmoed-Römer Heitman's conclusion is that the SADF's logistic effort "presented some serious problems". "The South Africans would also appear to have underestimated the difficulties of the terrain of south-eastern Angola." 19

The point is that the logistic support of the SADF north of the Chambinga, and even of 10 Division inside Namibia, was inadequate. One should not exaggerate the importance of this. The fact that the SADF could not - as their plan called for - annihilate the last Fapla bridgehead just across the Cuito River from Cuito Cuanavale was indeed, in part, caused by the shortage of supplies. However, the main reason lay elsewhere, in the inadequate thinking, which had gone into the plan in the first place. It lay in the assumption that the witness of all of military history (that frontal attacks against well-prepared defences are futile) could be simply ignored. ${ }^{20}$ But it is true that logistics did play a subsidiary role.

Therefore, lesson 2 is: Do not underestimate the role of logistics. The SADF's logistics should be able to support a sizeable force in difficult circumstances. This is all the more urgent in the light of the fact that the SANDF's logistic vehicles all date from the early eighties. The majority are 
in a shocking state of disrepair. It is no wonder the latest Defence Review states:

No defence force can function without reliable logistic vehicles that are suited to the nature of its operations and the terrain of the theatre of operations. The existing Samil fleet of trucks is old (30 years) and difficult to maintain, and will lack the mobility to effectively support modern combat vehicles. The bulk of the fleet must be replaced with suitable vehicles, including protected variants, as a matter of urgency. ${ }^{21}$

\section{The Role of Reserve Forces}

In most modern armies, reserve forces play an important role. For instance, in the light of the intensive strain the US military manpower was under since the 1990s, it was announced in 2004 that the US Defence Force would rely heavily on the 500000 reservists and National Guard members in order to sustain the wars in Iraq and Afghanistan. ${ }^{22}$

The SADF, of course, consisted mainly of conscripts serving for two years as the flesh around a skeleton of professional soldiers. This was backed up by the Citizen Force (CF), where ex-conscripts served for another eight years in regiments or area protection units, known by the traditional name of "commandos". These were called up from time to time when the SADF's operational needs required it. The CF units mainly provided counterinsurgency troops in the north of Namibia, but there were three instances when they were also utilised in considerable numbers in crossborder operations in Angola. The first was during Operation Reindeer in May 1978, the second was Operation Askari in December 1983 and January 1984, and the last during Operation Packer, the very last phase of the socalled Battle of Cuito Cuanavale in March-April 1988.

Utilising reservists has several peculiar problems, which have to be overcome if their deployment is to be a success. Some skills will never be forgotten. Even those who were trained decades previously will remember how to salute, about turn or even how to strip a rifle. Other skills degrade fairly quickly: fire and movement, clearing trenches and bunkers, clearing a way through a minefield, accurate artillery bombardments, combined armour and infantry attacks, etc. After all, these people will have become accustomed to a relatively soft civilian life. War is a cruel and gruelling 
business, which has very little bearing to what is considered ordinary and normal in civilian life. When calling up reservists, these military skills will therefore have to be relearned, and that may take some hard retraining and time.

With low-intensity counterinsurgency operations, such as infantry patrols, this may not be very apparent. However, with high-intensity conventional battles it is a different matter. Sending inadequately trained reservists into dangerous battles is doing them a great disservice. Yet this is exactly what happened during Askari as well as Packer.

During Askari, the CF soldiers were badly handled in that they were ordered to attack a well-entrenched enemy across disadvantageous terrain at the Fapla bastion of Cuvelai. They lost confidence in some of their officers and refused to carry out orders. In fact, the conscripts and professionals of 61 Mech had to be called in. Even then, the CF members refused to carry the brunt of the attack, which left the desperately tired 61 Mech soldiers to attack and overcome a determined defence. ${ }^{23}$ At a review meeting of the operation, it was bluntly stated that the CF battle group was the worst one of 82 Mechanised Brigade (from whence the battle group was provided). The morale of the CF elements was not up to scratch. ${ }^{24}$

One would imagine that the Army would have learnt something from this, but similar problems were experienced more than four years later during Operation Packer. Once again, 82 Mechanised Brigade was the vehicle for the mobilisation of a CF formation. The officer called upon to retrain the $\mathrm{CF}$ armour troops (in the event, he also led the two tanks squadrons into battle), Commandant (later Colonel) Gerhard Louw, felt that they were not ready for battle when ordered to move into Angola. ${ }^{25}$ Louw expressed himself even more forcefully to me:

To say that the CF troops had had insufficient training, was only the tip of the iceberg - they were in no way prepared for what was waiting for them. Beforehand they were as excited as naïve children before a picnic; afterwards many were ready for trauma counselling. The fact is, as an officer who chose the Defence Force as a career, I knew what they would go through and pitied them deeply. As a result of this I made unforgivable mistakes, like letting my frustration and doubts [about the attack plan] shimmer through to them during information sessions ... ${ }^{26}$ 
The fact is that these unprepared CF troops were expected to make a full-frontal attack on an enemy who had ample time to prepare itself, with numerous trenches, bunkers, reinforced minefields, massed artillery support and uncontested command of the air. In addition, it was to be the third attack against an enemy who knew they were coming - after two similar previous attacks had failed. It was tactical madness, even for seasoned troops.

The details of the failed attack are not very relevant for this article. Suffice it to say that the CF members were badly rattled by the ferocity of the defence and, through no fault of their own, did not fare well that day. ${ }^{27}$ In a document discussing the lessons of the campaign, harsh criticism was levelled at the citizen force units: "CF conventional training has been neglected a great deal in the past years, and CF units were utilised for the op[eration] which were not up to standard," it was stated. ${ }^{28}$

Of course, a prime example of where CF troops were indeed so intensively retrained that their operation was a huge tactical success, was the air assault on Cassinga on 4 May 1978. On that day, an under-strength, composite parachute battalion, consisting of mainly CF soldiers, was dropped on Cassinga. Although the drop itself went badly, the CF members subdued a much larger Swapo force within a few hours, albeit after some heavy fighting. ${ }^{29}$ Even then, some of the CF paratroopers, according to General Constand Viljoen, were not fit enough for a hard day's fighting. ${ }^{30}$

Against this background, lesson 3 is: Do not utilise reservists unless they have been adequately retrained for the job at hand.

\section{Anti-aircraft Capability}

The SADF's inadequate anti-aircraft capability remained a big problem throughout the war. The South Africans went into the war without a mobile anti-aircraft system suitable for the harsh African conditions, and ended the war in exactly the same position. They did have a 20-year-old Frenchdeveloped missile system, the Cactus (known in France as the Crotale), but it was designed as a more or less static base-protection system. It was taken to the front in 1987-1988, but proved too soft for the conditions, and was withdrawn after a few weeks. ${ }^{31}$ According to one source, only four Cactus 
missiles were launched at enemy aircraft in Angola, and one apparently damaged a MiG-21. The others all missed, which shows that the system was not a success. ${ }^{32}$

The other anti-aircraft system used in operations, was a hand-operated $20 \mathrm{~mm}$ cannon on the back of a Unimog lorry, known as an Ystervark (Hedgehog). ${ }^{33}$ One notable success of this system occurred on 26 June 1988, when eight Cuban MiG-23s attacked the Calueque waterworks in Southern Angola near the Namibian border. The aircraft came in so low that the pilots' faces and flight helmets could be recognised by the troops on the ground. A stray bomb killed 11 South African soldiers. The South Africans answered with Ystervark fire, and two MiGs were hit. One succeeded in returning to base; the other crashed. ${ }^{34}$

A few captured Soviet ZSU-23 guns $(23 \mathrm{~mm}$, much feared by the South Africans) accompanied the Cactus batteries, but there are no known instances of success. ${ }^{35}$ The SADF also had a towed twin 35-mm cannon, ${ }^{36}$ but their radar sets were damaged by and ineffective in the bush. ${ }^{37}$

The presence of these systems and Unita's American-supplied Stinger shoulder-fired missiles did, however, have one great advantage. Fearful of losses, the Cubans and Angolans (with the notable exception of 26 June 1988) stayed high, between 6000 and 16000 feet (between 1829 and 4877 $\mathrm{m})$. The result was that their bombing was very inaccurate, and only four SADF soldiers died as a result of enemy bombing. South African accounts frequently refer to enemy bombs falling way off target, although they did hamper the SADF's freedom of movement considerably. ${ }^{38}$

Since 1988, nothing much has been done to fill this gap in the SANDF's capacity. No new equipment was ordered, so the problem remains. As the 2012 Defence Review states, “The Defence Force currently lacks any modern air defence weapons other than a single battery of very short range missiles (Starstreak)." ${ }^{39}$ This means that any SANDF deployment in a part of Africa where an adversarial air attack position exists will be highly problematical. Lesson 4 is: Plug the anti-aircraft capability gap in the SANDF urgently. 


\section{Command of the Air}

It is an axiom that command of the air is a prerequisite for success on the ground. Elsewhere, I have illustrated with reference to Operations Moduler, Hooper and Packer that a "land campaign can be successful in the face of enemy aerial supremacy, provided that the enemy air force is militarily incompetent, like the Cuban and Angolan Air Forces". ${ }^{40}$ Nevertheless, it goes without saying that the SADF campaigns in Angola in the early eighties were much easier, amongst others because the SAAF then still commanded the air. By 1987-1988, the South Africans lost that position to the enemy. Although this was not enough to ensure their defeat, it did make things considerably more difficult for them.

It is important to analyse the reasons for the SAAF's loss of air supremacy properly. The superiority of the Cuban MiG-23 over the South African Mirage F1 has been greatly exaggerated. The MiG had only three advantages over the Mirage: It was faster (meaning it could run away when threatened), its range was longer, and it possessed a radar-guided missile, which could be fired from the front. The South African missiles were heatseeking and could only be fired from behind - and besides, they were of a poor quality and never worked properly. As for the rest, the Mirage was more manoeuvrable and handled by superior pilots. ${ }^{41}$

But the MiG's advantages were not enough reason for the SAAF's loss of air supremacy. The main reason was geography, something the South Africans could do little about. Whereas the Mirage F-1CZ (the fighter version), being relatively light, could take off from Rundu Air Force Base with its short runway, the heavily-laden F-1AZ (the bomber version) had to take off from Grootfontein, about 500 kilometres to the south. During the fighting north of the Chambinga River in 1988, the SAAF aircraft required 42 minutes to reach the combat area. This meant that they had exactly two minutes of combat time before they had to break off and head back for home. In contrast, the Cuban MiGs were based at Menongue, only nine minutes away. They could, therefore, loiter for about an hour over the battlefield, looking for targets of opportunity. To be sure, the SAAF had acquired Boeing 707 tanker aircraft, but these were not used. Having (at that stage) only three of them, the Air Force did not want to risk them being 
shot down, and besides, the pilots were not yet proficient in being refuelled in the air. ${ }^{42}$ This meant that the SAAF's potential was greatly curtailed.

Of course, in the years since the war, the Air Force acquired considerable expertise in air refuelling with its five Boeing 707s and the Cheetah fighters. But the Boeings were withdrawn from service in 2007 due to age. ${ }^{43}$ The Mirage and Cheetah have since also been replaced by the Saab JAS-39 Gripen, which is a superb aircraft, but it suffers from the same problem as the Mirage, namely an insufficient range. And, having cancelled the Boeings' replacement, the Airbus A400M, the Air Force's legs are as short as ever in its history. Any operation far from home will therefore have to take the Gripen's lack of endurance into account.

Lesson 5: Get a suitable tanker aircraft and do it quickly. This has big strategic implications. Also, the Border War proved the worth of excellent pilot and air and ground crew training. No compromise is possible.

\section{Air Assault and Maritime Landing}

Air assault and maritime landing mostly did not play a prominent and visible role in the Border War. Paratroopers were indeed extensively used, but as helicopter-borne quick reaction forces (the so-called Romeo Mike units, an adaptation of the Rhodesian Fireforce tactics) in the counterinsurgency war in northern Namibia, and as motorised infantry during some cross-border operations. ${ }^{44}$ The only exception was the parachute assault on Cassinga in May 1978.

Nevertheless, plans did exist for a huge combined air and maritime assault in 1988 on the Angolan port town of Namibe. This was after Operations Moduler, Hooper and Packer (or the so-called Battle of Cuito Cuanavale) had ended, and Namibia was threatened by the southward advance of the Cuban 50 Division in the province of Cunene down to the border. The SADF at first mulled the idea of a pre-emptive strike to destroy the Cuban force before it could invade Namibia, but because of several reasons decided to wait and see whether the Cubans would try to cross the border, and then hit back. 
One element of this plan was an assault by 14 Parachute Battalion Group, a unit of about a thousand paratroopers and support troops, all parachute-trained. The idea was to attack Namibe, the only harbour in Cunene and the main entrance point of supplies. The troops would be dropped by aircraft and landed from South African Navy combat support ships, escorted by Navy strike craft, which would also provide light artillery support. The idea was to destroy the harbour and railway lines, and withdraw after dark to the Navy vessels to be transported back to Namibia. ${ }^{45}$

As the Cubans never invaded Namibia, this operation obviously was not carried out. But it nevertheless did have a significant strategic effect. To prepare for the operation, Exercise Magersfontein took place in the first half of 1988, when the landing was rehearsed at Walvis Bay. That made an impression on the Cubans. According to Rear Admiral Chris Bennett, "a very senior Cuban Army officer" on a visit to Simon's Town in 1989 admitted that one of the factors that had finally led to Cuba supporting the termination of the conflict with South Africa, was a major naval exercise (Exercise Magersfontein) conducted from Walvis Bay during 1988. Of interest is that the reason for putting on this large, extremely complex and highly publicised exercise at such very short notice, was to pass the message that the SA Navy was capable of escalating the maritime aspect and that it could also support its fleet fully from a forward base. ${ }^{46}$

Mac Alexander, a seasoned paratrooper himself, describes the SANDF's diminished airborne capability:

Today the paratroopers of 44 Parachute Regiment have the ability to deploy no more than two or at the most three infantry companies by air, supported by light weapons of limited range, over relatively short distances and for very brief periods. This restricts them to airborne operations such as backing up the Special Forces Brigade, small-scale counter-insurgency operations (such as Fire Force) or providing a large conventional force such as a mechanised brigade with a small airborne arm for ancillary tactical operations. There can be no question of independent airborne operations against a distant, strategic objective. Nor even an independent long-distance interventionist operation to rescue South African nationals or protect South African interests. The airborne logistic requirements alone would make this impossible. ${ }^{47}$

This brings us to lesson 6 of the Border War: Even though an air assault and amphibious capability may seldom or perhaps even never 
become necessary, it provides a strategic output quite out of proportion to the financial and personnel input. But then, of course, you need the necessary strategic air- and sealift - something the SANDF at present does not possess with only seven serviceable C-130 transport aircraft and only one somewhat elderly combat support ship, SAS Drakensberg. ${ }^{48}$ This needs to be rectified, as it does not take a lively imagination to see the possibility of having to subdue rebel militias, perhaps holding civilians hostage, either in an inaccessible area or elsewhere near the coast. Having an air assault and amphibious capability gives one the flexibility and ability to launch lightning operations with limited objectives without having to commit large assets.

\section{Incremental Commitment}

One of the biggest problems from a South African perspective in the Border War was the question of "mission creep" - the incremental way South Africa got involved in the Angolan Civil War. This happened twice, in 1975-1976 and again in 1987-1988.

Admittedly the situation in Angola in 1975 was extremely chaotic and fast-moving, not at all conducive to a calm, reasoned analysis of the events, South Africa's interests and the way the country should react. Hard intelligence was scarce, and more often than not decisions had to be made on the basis of rumours.

In short, the situation was this: After the military coup d'état in Portugal in April 1974, the new government quickly decided to pull out of the country's African possessions. Whereas there was only one liberation movement each in Mozambique and Guinea-Bissau, thereby greatly simplifying things, in Angola there were three. They were the Marxistoriented MPLA, the FNLA (corrupt, without an ideology and ineptly led), and the Maoist Unita. Already by the end of 1974, the Soviet Union and Cuba started funnelling arms, instructors and money to the MPLA in the hope of turning Angola into a communist bastion and winning an important geostrategic advantage over the West. The Portuguese, eager to wash their hands of Angola, signed the Alvor Agreement in January 1975 with the three movements. This established an interim government of national unity 
with the task of organising free and fair elections. The independence date would be 11 November. ${ }^{49}$

When violence broke out in Luanda between the three and the FNLA and Unita were forcibly expelled from the city, the Alvor Agreement crumbled. The Soviets and Cubans quickly moved to fill the power vacuum, which was viewed with considerable alarm by the West and certain African countries. As these countries were fairly powerless to do something about it, they turned to South Africa to stop the communists taking over Angola. A communist Angola, allowing the Namibian rebel movement Swapo to use its territory to wage an insurgency war in Namibia, was viewed as being very much against the South African interests.

Nevertheless, the South African government clearly was caught on the wrong foot and did not know how to react. Besides, the government was deeply divided - the Security Police establishment and the Department of Foreign Affairs wanted to handle the matter diplomatically, while the SADF burned with desire to cross the border and sort the problem out militarily. Under pressure from especially the United States and some African countries, and specifically requested to help by Unita leader Jonas Savimbi, South Africa was slowly but surely sucked into a cauldron without a clear understanding of what its aims were and how to reach them. This obviously impacted negatively on the frontline troops. As Commandant (later Colonel) Jan Breytenbach, commander of one of the invading columns, later wrote:

At the sharp end, during Savannah, we never really knew whether we were to take over the potential SWAPO guerrilla base area by destroying the guerrillas already in residence there, capture as much of Angola as possible before 11 November, attack and take over Luanda, the capital, to install Savimbi ... or "whatever". As combat soldiers, we hardly knew what the hell was going on and where we were going to. But we went nonetheless. ${ }^{50}$

Be that as it may, the first step was the supply of weapons to Unita. But then it was established that Unita did not know how to operate them, so the second step was to send weapon instructors. Finally, Prime Minister John Vorster was cajoled into allowing SADF officers and NCOs clandestinely to take command of FNLA and Unita troops and organising several battle groups to combat the Cuban-supported MPLA southward 
advance. These battle groups moved at a blistering pace northwards, catching the enemy unawares time and again, and achieved great success. But the battlefield success generated new needs. As time went on, and as it became clear that thousands of Cuban troops were being poured into Angola, more and more SADF forces were committed: artillery, armoured cars and conscripts, even citizen force regiments - in the end about 2900 South African soldiers were involved in Angola. Even Defence Minister PW Botha acknowledged during a Cabinet meeting in December 1975 that South Africa had been sucked into the civil war further than the original idea was. ${ }^{51}$

Of course, we know today that the brilliant tactical success of Operation Savannah, as the SADF involvement became known, masked a strategic catastrophe of considerable magnitude. It marked the end of Vorster's attempt to reach out to black Africa in order to gain acceptance for his apartheid government and placed South Africa on the one hand, and the Southern African liberation movements, Angola, Cuba and the Soviet Union on the other, on a collision course. Also, South Africa's political backing in America, Europe and Africa evaporated. In these circumstances, South Africa had no choice but to pull back its forces to Namibia.

In the aftermath, the SADF conducted an extensive review of the Operation. Considerable equipment gaps were identified and an intense attempt to fill them up was embarked upon. ${ }^{52}$ More importantly, attention was also given to the strategic level. Brigadier General George Kruys, who played an important part during Savannah as South African commander at the pivotal Battle of Bridge 14, later summarised one of the conclusions of the review:

The fog which descended from the political level and obscured the view of the field commanders would be evaded. The aim of future operations would be precisely formulated. Incremental and extended involvement was out; operations would start with sufficient forces and would be of limited endurance.

He added, "After Savannah, operations were planned in detail in terms of time in, time out and exactly what was to be achieved while in Angola as well as how the operation was to be co-ordinated and executed." 53 
This important lesson was strictly adhered to in the years to come. All the big cross-border operations - Reindeer (1978), Rekstok and Saffraan (1979), Sceptic (1980), Protea (1981), Askari (1983-1984), Weldmesh and Wallpaper (1985), and Alpha Centauri (1986) - were limited in scope, forces and time involved. The political and military objectives were well defined so as not to have the situation escalate. It worked well.

However, all this was thrown overboard when Fapla, the Angolan Army, began a huge offensive against Unita in September $1987 .{ }^{54}$ For reasons of self-interest, which need not interest us here, South Africa decided to aid its ally. But it was once again, as in 1975, done in a chaotic, clumsy and incremental way.

First, special forces were sent in as anti-tank teams, but as Fapla infantry screens protected their tanks, the South Africans could not get near enough. (This Fapla tactic was standard operating procedure in every modern army, which begs the question how such a naive decision could have been taken.) The second stage was the decision to send in three motorised infantry companies from 32 Battalion and a Valkiri multiple rocket launcher battery. This would take place while the Army's premier heavy unit, 61 Mechanised Battalion Group (61 Mech) and the Air Force were allowed to ready themselves for battle in case they were needed. When 32 Battalion's aid proved too little, 61 Mech, additional artillery and the SAAF were also released. But the generals put severe restrictions on them, as summarised by Fred Bridgland: "No men must be lost, no equipment must be lost, and you must achieve all your objectives." All this had to remain clandestine - "plausibly deniable", in Bridgland's words. ${ }^{55}$

This was absurd. 61 Mech alone consisted of about a thousand men with a convoy of 125-130 vehicles, and the 32 Battalion elements have to be added also. To expect a force of this size to clash violently with Fapla and expect it to remain a secret, testifies to the SADF leadership's naïveté.

But it did not end here. This force became involved in a series of battles with Fapla along the Lomba River, during which two of the four advancing brigades were severely mauled and another all but destroyed. A few days before the final clash, President PW Botha, on a visit to the front, gave his blessing to a counteroffensive to hit Fapla so hard that it would not 
be able to renew its offensive before the end of 1988. To this end, 61 Mech's sister unit, 4 SAI, was brought in, together with additional artillery and a tank squadron (which was later augmented with a second squadron). This brigade-sized force of about 3000 men then drove Fapla back across the Chambinga River in a series of hammer-blows. Yet, it took until 11 November before the Chief of the South African Defence Force (CSADF), General Jannie Geldenhuys, acknowledged South Africa's involvement in Angola. Jan Breytenbach quite correctly refers to the "fatally flawed incremental nature" of the decision-making process. ${ }^{56}$

This was directly responsible for the fact that Operations Moduler, Hooper and Packer lasted eight full months, something the SADF could ill afford from a political (and logistic) viewpoint. In a review of the three operations, the following rather brave statement (brave, because it implies sharp criticism of the Defence Force leadership) was recorded: "According to policy and doctrine the SA Army only does 'blitzkrieg' operations across the border, a maximum time of 30 days is stipulated, and logistic and other planning is based on this. Present ops are slow and last months." 57

It is clear that the lessons of Operation Savannah were totally ignored in 1987, as the two operations developed in much the same way incrementally, initially without a clear political objective and with a remarkable disregard of the principles of warfare. A review document of the lessons of the war also refers to a "perception that there is a lack of formal appreciation on C Army level", which is defined as "the making of a specific strategy appreciation and plan which can be deployed against that of the enemy”. It was recommended in the review that the executors be involved in the planning at sector level - in other words, that the field commanders participate in the formulation of the military strategy governing an operation. ${ }^{58}$ This seems a rather severe criticism of the chaotic way in which the SADF was drawn into the operation, mainly because of a lack of clear strategic thinking at the very top. In fact, it may be said that the SADF planned battles instead of an operation.

Lesson 7 would, in other words, be: Be clear in your own mind what the political, economic and military parameters of any operation are, decide right from the beginning what you want to achieve and how you want to do it. 


\section{Micromanagement of the Battlefield}

According to the American military writer, Robert Leonhard, the Germans distinguish between two categories of command and control. The one is called Befehlstaktik, or "control by detailed order"; the other Auftragstaktik, or "directive control". (Elsewhere, the first is also known as "mission command".) The essence of the first, he says, is that the commander issues detailed orders, leaving subordinate commanders little freedom to deviate. Rather, the smaller units all move and fight according to the plan. Under this method, the key to victory is not to exploit opportunity, but to impose the commander's will upon the enemy with irresistible momentum through unified action. ${ }^{59}$

Auftragstaktik, on the other hand, is described as a method of command in which the commander (company, division, army group, etc.) communicates his intent with regard to the enemy as well as the mission of the friendly unit involved. The commander adds the details that are absolutely necessary to facilitate the coordinated actions of his subordinates, but he refrains from telling them how to go about accomplishing the task. Rather, he lets them use their expertise, their more intimate knowledge of their own men and equipment, and their greater familiarity with the terrain to develop their own methods. The only constraint is that they must stay within the commander's intent. ${ }^{60}$

Without using the word as such, Auftragstaktik was the way the SADF normally operated. Roland de Vries explained:

The South African combat leaders were afforded a great measure of initiative down to battle group and combat team level. This stimulated independent thought and conduct to a great extent down to ground level. The FAPLA enemy did not have this powerful and flexible attribute. The poor devils had to ask permission for everything and were not allowed to think for themselves. ${ }^{61}$

A good illustration was the way SADF generals used to accompany cross-border operations in the early years of the war in order to get a "feel" for what happened at grassroots level during operations. After all, they were too young to have participated in the Second World War, but too old to fight in the Border War, ${ }^{62}$ and this was their only way to stay in touch. Thus, in May 1978, the Chief of the Army, Lieutenant General Constand Viljoen, 
turned up at Cassinga with the first wave of helicopters to extract the paratrooper force. Although Colonel Jan Breytenbach, the attack force commander, thought he was "an extra pain-in-the-neck", ${ }^{63}$ Viljoen confined himself to observing and did not meddle.

Two years later, Viljoen accompanied Combat Group 61's commander, Commandant (later Major General) Johan “Dippies” Dippenaar during Operation Sceptic, the mechanised attack on the Swapo base complex known as Smokeshell. Once again, he scrupulously allowed Dippenaar to use his own initiative and never intervened. In his report about the operation, Dippenaar wrote about Viljoen -

... his inexhaustibility and activity was at that stage my biggest worry. The best I can describe General Viljoen is undoubtedly like an ant, because whenever there was a chance, he walked about, looked at equipment and talked to the soldiers. At no stage did he interfere with my command, although, from time to time and when asked, he gave his opinion. ${ }^{64}$

Again, in 1981, the next C Army, Lieutenant General Jannie Geldenhuys, went along for the ride when 61 Mech assaulted Swapo bases during Operation Daisy. Roland de Vries, OC 61 Mech, testified:

He remained with us until the attack on Chitequeta was completed on 4-5 November 1981. He travelled with me and my crew in my command Ratel; he acted as part of the crew and never imposed on my command. ... It was both comfortable and pleasant to have General Jannie Geldenhuys with us. It had a tremendously positive effect on the morale of our troops. It was an extraordinary mark of the generals of the SADF to accompany soldiers into battle, right up to the front-line. ${ }^{65}$

This worked well. It afforded the generals good experience without restricting the field commanders' freedom to exercise their own initiative, albeit within the broad parameters of the operation. But this changed with Operations Moduler, Hooper and Packer in 1987-1988. We have seen how the SADF units in the beginning were saddled with heavy - one might say absurd - restrictions, and how these were progressively discarded as the SADF became sucked into the cauldron. There are several examples of generals on flying visits to the front, wanting to approve tactical battle plans in considerable detail and demanding changes. For instance, while on a visit to the front on 23 December 1987, Jannie Geldenhuys (in the meantime 
promoted to CSADF) insisted that Colonel Paul Fouché, OC 20 SA Brigade, present his battle plan for driving a wedge into Fapla's defence line north of the Chambinga. Fouché duly did so, but Geldenhuys was not satisfied. He accused Fouché of being "too aggressive" and risking too many casualties. He told Fouché to rely more on "psychological action", to concentrate the attack on just one enemy brigade and to let Unita initiate the attacks. Fouché had no choice but to change his plan. ${ }^{66}$

Of course, the details of Fouché's original and amended plans are not relevant for this article. What is relevant, is - for the SADF - the unique phenomenon that a full general intervened in a tactical battle plan, which, according to the SADF's own doctrine, should have been the prerogative of the local tactical commander. The Auftragstaktik followed by the SADF meant that Geldenhuys should simply have made sure that Fouché's intentions were in sync with the broad guidelines for the operation, nothing more.

Another example was the battle plan of Fouché's successor, Colonel Pat McCloughlin, for attacking the Tumpo Triangle on 25 February 1988. His plan had to be approved by Lieutenant General Kat Liebenberg, C Army, and even by the Minister of Defence, General Magnus Malan. Liebenberg made some minute changes to the plan. ${ }^{67}$

Something similar happened during the second attack on Tumpo on 1 March 1988. McCloughlin's attack was stopped by a combination of cleverly placed minefields, massed artillery fire from the opposite bank of the Cuito and air attacks without having made contact with the Angolan defenders. With his attacking force dead in the water, McCloughlin should have been entitled to withdraw on his own authority. But at least two generals had turned up to watch the battle, including Kat Liebenberg and Major General Willie Meyer, OC South West Africa. McCloughlin first had to get their permission, which was granted. ${ }^{68}$ Yet again, during the third Tumpo attack on 23 March 1988, when the South African attack was once more stopped, three tanks were damaged so severely in a minefield that they had to be abandoned when the troops withdrew. Paul Fouché, who had returned to the front as tactical commander, wanted to destroy the tanks with his artillery to prevent them from falling into enemy hands. But Liebenberg intervened and forbade it. He said the tanks could be recovered 
afterwards. ${ }^{69}$ This proved to be greatly naive, as the enemy immediately took possession of the battlefield and carted the one moveable tank off to show to the whole world how the South Africans had been beaten in the Battle of Cuito Cuanavale.

It is clear that this caused considerable tension between the generals and the field commanders. In a secret review document about Operations Moduler, Hooper and Packer, the following forthright words were recorded: "During the op, there was a deviation from the principle that subordinate commanders should have reasonable freedom of conduct ('mission type orders')". ${ }^{70}$ Roland de Vries' comment to me was, "We had much frustration on the ground at the time. On the ground it was mission command, at the top rigid Befehlstaktik á la over-control.,"71

In another secret SADF review of the lessons of the war, it was recorded:

Because well-thought out plans, according to the opinion of the planning groups, were presented and turned down, it caused, apart from the frustrations, a degree of uncertainty with the commanders about what was expected of them. This uncertainty filtered through to the lower levels, which caused morale problems.

The reasons why these plans were shot down were not explained to the officers, according to the document. It was recommended that planners at every lower level be made privy to the thinking of those at the next higher level. ${ }^{72}$

To be sure, there were extenuating circumstances for the generals' intervention. After the war, the above-mentioned review document acknowledged, "[t]he SA Army must accept that it is an instrument in the hands of the State and that the political situation will have a direct influence on the choice of objectives and targets." Revealing the tensions between the generals and the field commanders, the review bluntly stated,

... subordinate headquarters must accept the guidelines as issued by the higher headquarters and do their planning within those guidelines, and not do the planning to "prove" that the guidelines/restrictions cannot work. "Fight the war with the restrictions and not the restrictions." 
Clearly reflecting the viewpoint of the generals, this part of the document specifically referred to the question of casualties, which was politically very sensitive. Those battle plans which were approved, might not have been the best plans from a pure operational perspective, but: "The risk of casualties amongst especially certain personnel and equipment is an important and decisive factor in many instances." 73

Against this background, the document recognised that some field commanders experienced the fact that generals had to approve battle plans first as looking over their shoulders "because of a lack of confidence in the individual in question as commander". ${ }^{74}$ Nevertheless, as far as the visits of general officers to the front is concerned, it was stated that as they carried the final responsibility, they -

experienced a need to be as close as possible to the battle so that the battle could be influenced within the framework and the guidelines/restrictions which were placed by the political arena on the SA Defence Force. The need was to be present to support the commanders by approving/taking critical decisions on the ground and directly.

Commanders had to be taught, the document stated,

... to accept that $\mathrm{H}$ Army and other senior personnel from Army Headquarters would move to the front to approve plans. The matter should not be seen as a threat, but rather exploited by commanders to clear up uncertainties in their own mind as to what is expected. ${ }^{75}$

Helmoed-Römer Heitman, too, ascribes the micromanagement of the battlefield to the "political nature" of the campaign. The generals "naturally wished to be where they could see and sense what was happening, rather than sit in Pretoria relying on telexes.” Nevertheless, his final conclusion was not favourable:

[T]he campaign of 1987-88 in Angola is not an example that the SADF should look at when considering its command and control doctrines. Any attempt to control a less politically sensitive campaign in this way would be entirely wrong. Commanders must be given a mission and some simple guidelines and then left to plan and execute it. The senior generals must get on with their work at the strategic level. Even given the very difficult circumstances of this campaign, there does seem to have been too much input from high level. 
This seems like a very sensible conclusion. Lesson 8 is that if you have well-trained officers on the battlefield in whom you have confidence, leave them to do their thing as they know best. As long as their tactical plans and moves fit in with the general parameters of the operation as such, do not intervene lightly. The SADF knew this truth and practised it faithfully during most of the war, but deviated from it in the last months. And this was not to the advantage of the South Africans in their battles.

\section{The indirect approach and mobility}

The First World War, when 10 million soldiers died, was characterised by stupid mass frontal infantry attacks across terrain without cover against impregnable defences. This caused a British infantry captain, invalided out of the military in 1916 after a German gas attack, to reflect how war could be waged more intelligently. His name would become writ large over the $20^{\text {th }}$-century military history: Sir Basil Liddell Hart. ${ }^{76}$ Over the years, Liddell Hart formulated his ideas about an indirect approach in several books and articles, basing them on his interpretation of military history since antiquity. ${ }^{77}$ His basic point of departure, he explained near the end of his life, was never to launch an offensive or attack "along the line of natural expectation". To do that, would be "to consolidate the opponent's equilibrium, and by stiffening it to augment his resisting power". Based on this, he made two points:

The first is that in the face of the overwhelming evidence of history no general is justified in launching his troops to a direct attack upon an enemy firmly in position. The second, that instead of seeking to upset the enemy's equilibrium by one's attack, it must be upset before a real attack is, or can be successfully, launched..${ }^{78}$

Liddell Hart's ideas have since been expanded by other writers, but essentially they stand as an exposition of common sense and an intelligent approach to warfare.

Liddell Hart's work made a deep impression on at least one fairly influential South African officer, Major General Roland de Vries, who ended his career as Deputy Head of the Army. As OC 61 Mech, he participated in Operations Protea and Daisy in 1981. As second in command of the South African brigade (under Colonel Deon Ferreira) 
during the second stage of Operation Moduler, he was mainly responsible for the defeat of the Fapla brigades in the counteroffensive, which took the SADF from the Lomba to the Chambinga. ${ }^{79}$

All these operations were characterised by rapid, mechanised movements to keep the enemy off balance, and by the indirect approach. Under his (and Ferreira's) able direction, Fapla was repeatedly and rapidly outmanoeuvred and blindsided, attacked from unexpected directions and misled as to the South Africans' real intentions. That the South Africans did not defeat the enemy even more soundly during the advance on the Chambinga was due to factors beyond the control of De Vries and Ferreira, chiefly because they never had adequate forces at their disposal.

Liddell Hart's indirect approach featured heavily in a book on mobile warfare, which De Vries published a few months before Moduler. He even devoted an entire chapter to it, and repeatedly referred to it elsewhere in the book. "The purpose must thus be to outmanoeuvre the enemy in a resourceful way, rather than to get involved in a head-on full-scale confrontation - Blood is certainly not the price of victory," he wrote. ${ }^{80}$

De Vries' ideas were entirely in sync with the mobile conventional warfare doctrine developed by the mechanised brotherhood in the SADF during the late sixties and seventies under Constand Viljoen's initiative. This doctrine was summarised by Viljoen as being

... based on not to hold ground but to create the design of battle in such a way that you would lure the enemy into [a] killing ground and then [utilising] the superiority of firepower and movement, you would kill him completely. ... Never think about a battle that could compare with El Alamein, it's completely impossible. In Africa you don't operate that way. ${ }^{81}$

In other words, instead of the holding and occupation of territory being the fundamental points of departure, factors like rapid movement (mobility), getting in the enemy's rear areas, surprise and misleading the enemy would become instruments to make it impossible or difficult for the enemy to fight in the first place.

This mobile doctrine was followed in all major cross-border operations during the early eighties. At a tactical level, it was also followed 
during the battles at the Lomba and the march to the Chambinga. However, on a military-strategic level, the SADF leadership - clearly not being impressed with Liddell Hart or Roland de Vries - deviated from it right from the start of Operation Moduler. Somewhat oversimplified, the South African leadership had two choices in how to counter the Fapla offensive against Unita. One was to confront the enemy head-on where he was, stop him and drive him back all the way to whence he came. This was, in other words, east of the Cuito River, which flows from south to north and divides the province of Cuando Cubango basically in two. Or, alternatively, slip around the enemy's flank west of the Cuito, advance deep into his rear areas, cut his communication lines and attack him from behind. In fact, a continuing debate about these options raged behind the scenes in the South African Army, but the "easterners" won the argument each time. ${ }^{82}$

This decision had important consequences. It is true that Fapla's advance was stopped at the Lomba, and that the Angolans were then driven back to the north of the Chambinga, both phases of the operation being brilliantly handled at a tactical level. But, once they were north of the Chambinga, the South Africans had little choice but to unleash a series of full-frontal attacks on the ever-stiffening Angolan defences. Their ferocity was enough to defeat and drive back the enemy several times. But then a final three attacks on the remaining Fapla bridgehead at Tumpo were rebuffed decisively, and the South Africans reeled back with a bloody nose each time.

The fact is that the SADF's own mobile doctrine was ditched. It made way for an attritionist approach, which reminds one to some extent of the First World War - exactly the kind of thing Liddell Hart and De Vries warned against. That this happened against the wishes of the field commanders, changed nothing.

The military historian Dave Palmer writes about attrition:

Attrition is not a strategy. In is, in fact, irrefutable proof of the absence of any strategy. A commander who resorts to attrition admits his failure to conceive of an alternative. He rejects warfare as an art and accepts it on the most nonprofessional terms imaginable. He uses blood in lieu of brains. ${ }^{83}$ 
On the other hand, W.S. Lind describes manoeuvre warfare thus: “The goal is destruction of the enemy's vital cohesion - disruption - not piece-bypiece physical destruction. The objective is the enemy's mind, not his body. The principal tool is moving forces into unexpected places at surprisingly high speeds." ${ }^{\prime 4}$ This insight, which was very much part of the SADF's collective consciousness until 1987, was then abandoned. Once again, political factors played a part. But this side of the campaign, like the others referred to above, were clearly mismanaged at a strategic level.

This brings us to lesson 9: The SADF mobile doctrine paid off where it mattered, on the battlefield. Why the South African generals deviated from it has never been adequately explained. Their attritionist approach was directly responsible for handing the Cubans and Angolans a propaganda victory on a platter. Mobility and the indirect approach need to be part of the SANDF's doctrine.

\section{The Need for Officers' Intellectual Education}

This brings us to the question of an intellectual education for officers. Many of the mistakes made in war, writes the naval historian Philip Crowl, "have been, at root, failures of the imagination, failures of the intellect. The strategic problem is essentially an intellectual problem.” ${ }^{85}$ The way the SADF generals directed Operations Moduler, Hooper and Packer testifies to exactly this $-\mathrm{a}$ failure of the intellect.

A typical example of this mind-set came from the late Brigadier General J.N.R. (“Junior”) Botha, who was, as a colonel, SSO Operations in Army HQ during these operations. Shortly before his death, he attacked me harshly for daring to distil theoretical military principles from the writings of amongst other Clausewitz and Liddell Hart for a critique of the SADF command's handling of the war in Angola in 1987-1988. He wrote: “The theories of these writers, and many others, are precisely that: theories. They have never been tested in a real war. They are distanced so far from reality that they are simply of academic importance!”86 One can only describe this - very un-academically - as utter claptrap, as anyone who knows anything at an intellectual level about warfare will testify.

In a much-quoted passage Professor Annette Seegers writes: 
From the time of Union, debates about the Department of Defence held that military experience counted more than intellectual or staff ability. Staff courses and later joint staff courses at the Defence College favoured those with operational experience, the line officers. The SADF wanted innovative soldiers. The abstractions of staff officers would spoil them. Even for its elite, the SADF thought theory best ignored. ${ }^{87}$

She cites the example of Brigadier Willem van der Waals, "one of the SADF's chief authorities on COIN. Yet he never reached the pinnacle of the SADF's hierarchy. The SADF simply did not believe in rewarding thinkers." ${ }^{88}$ As far as is known, Van der Waals is the only officer being awarded a Ph.D. ${ }^{89}$ on a military-related subject while still serving in the SADF. He also came first on the SA Army's prestigious command and staff course. But a senior officer who prefers remaining anonymous, told me that Van der Waals' promotion to Major General was blocked twice while Jannie Geldenhuys was CSADF because Van der Waals was deemed too outspoken. After Geldenhuys' retirement, Van der Waals was indeed offered promotion, but opted instead for early retirement and a second career.

Another officer who, in spite of his lack of an academic education, had made a thorough intellectual study of warfare, was Roland de Vries. At the end of his book, based on his own experience in the Army, he wrote what may be seen as an attack on the rigid mind-set promoted in the military. He referred to a "dogmatic and subjective approach in training. Leaders under training are forced to think like their predecessors and tutors. ... Because of this approach we curtail creative thinking." Students thinking out of the box are slapped down as "not according to doctrine", to the detriment of flexibility and initiative. He then quotes Liddell Hart: "Mobility of thought implies originality in conception and surprise in execution." 90

Does this not support a conclusion that the SADF's failure at the very end of the Cuito Cuanavale campaign was due to the lack of proper understanding of warfare at general level?

Already in 1980, military writer Helmoed-Römer Heitman said in a thoughtful article that many officers in the SADF "rarely bother to do more 
than glance at the professional journals ... One could be forgiven for receiving the impression that our army is illiterate.”

He continued:

This is an extremely serious problem: a profession that neither reads nor writes cannot but stagnate and an army suffering from mental stagnation is well on the way to losing its next war. The whole value of individual professional military writing lies, after all, therein that it allows and encourages the formulation, exchange, development and dissemination of new ideas and concepts. This stimulation and furtherance of military intellectual activity is essential to the continued effectiveness of an army. It can only be achieved through the open forum of professional military journals and, not least, their letter pages. It cannot be achieved by means of mechanical official writing, the letters, memos, reports, handbooks and manuals that abound in every army. ${ }^{91}$

Lieutenant Colonel Professor Abel Esterhuyse, strategist at the Military Academy at Saldanha, refers to a distinction between two elements in the making of an officer: Training and education. Both are needed:

The military in fact often approach the problem of differentiating between the two by ignoring the difference. The underlying philosophy and the fundamental aims and objectives of education clash with those of the military in general and military training in particular. Good training produces officers who will respond instinctively in anticipated, recognisable circumstances in a manner circumscribed by their training. Training does not teach the officer "how to think" but rather "what to think". Education, on the other hand, instils the mental flexibility to look beyond the horizon, to anticipate and to shape the future. ... For militaries, it is important to understand the difference and tension between training and education because they have to cope with it. The military cannot afford to neglect either the training or education of its forces since each has its own importance dictated by its own domain. It is after all possible to lose a war without losing a single battle - in the military world of tactics where the training of forces is decisive. Becoming involved in dangerous conflicts in a war-torn continent like Africa because of bad strategic choices can also be disastrous - in the world of strategy where education is essential. ${ }^{92}$

Lesson 10: Do not limit the making of officers to training. Combine their training with a proper education so that they might understand more than the question how to cross a river, kill the enemy on the hill on the other side, and how to move - say - a mechanised battalion group from point A to 
point B. At the very least, those promoted to general rank must have a sophisticated education into the nature of war.

\section{Conclusion}

The institutional memory of the SANDF about the Border War - after all, South Africa's single biggest operational experience after 1945 - is slowly dying out. The surviving ex-SADF component is slowly moving towards retirement. Those who came to the SANDF from MK and Apla sometimes regard the Border War as ideologically tainted and do not want to engage in disseminating the conflict from a professional and ideologically neutral vantage point. This is wrong. The Border War is as much part of the SANDF's history as MK's struggle against the National Party government, or for that matter, the First and Second World War.

This article is an attempt to defuse the Border War in a professional way so that military officers may profit from it. Obviously, the lessons of that war have only been touched on; much more may be written about it. But hopefully these - and other - lessons will be taken to heart in order to improve the functioning of the SANDF in the interest of South Africa.

1 L Scholtz. The SADF in the Border War, to be published by Tafelberg in 2013.

2 Len Deighton has written a brilliant concise analysis of the German Panzer Division in Blitzkrieg: From the rise of Hitler to the fall of Dunkirk. London: Jonathan Cape, 1979, 77-79. Cf. also K Macksey. Panzer Division: The mailed fist. London: Macdonald, 1978, passim. Lt. kol. TE Crisco, Jr.“Division operations”. Military Review JanuaryFebruary 2006. 95-100. Cf. graphic in T Clancy. Armoured warfare: A guided tour of an armoured cavalry regiment. London: Harper Collins, 1996, 188-189.

5 OPS/309/1/Reindeer: Verslag: Ops Reindeer: Aanval op Teiken Bravo 4 Mei 1978.

<http://www.61mech.org.za/assets/files/mediafiles/d503350c91a7e3c49c83d1 9d1dfa3cb446b78137_1.pdf >

$6 \quad$ J Dippenaar. 1979. <http://www.61mech.org.za/years/1979>

7 H-R Heitman. Krygstuig van Suid-Afrika. Cape Town: Struik, 1988 , 44-46.

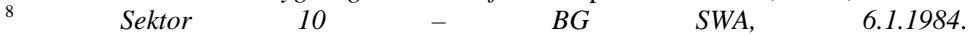
<http://www.61mech.org.za/assets/files/mediafiles/c14357d42e904f9a6382ff0 e8f7561c70d038f3a_1.pdf $>$.

$9 \quad$ E-mail from E van Lill, 18 April 2011. 
E Jordaan. "The role of South African armour in South West Africa/Namibia and Angola: 1975-1989”. Journal for Contemporary History 31/3, December 1986. 54.

E-mail from Col. A Retief, 25 April 2011.

Lesse geleer tydens konvensionele operasies in die westelike subteater, Chapter 1, paragraph 14 (document provided by R de Vries).

These matters are dealt with in detail in my forthcoming book about the Border War.

Lesse geleer ... op. cit., Chapter 1, paragraph 14.

Ibid., Chapter 20, paragraph 8.

Ibid., Chapter 1, paragraph 12.

See my forthcoming book.

H Leër/D Ops/309/4 - Prone. Notas vir aanbieding aan SVR mbt operasies in Suid Angola: SA Leër, Julie 1988 (group 4, box 160, HSAW 3009/4), 133134.

H-R Heitman. War in Angola: The final South African phase. Gibraltar: Ashanti, 1990, 345.

This is also analysed at length in my book.

SADF. "Defence, security and development". South African Defence Review, 2012, Chapter 13, paragraph 166.

E Schmitt. "Army retraining soldiers to meet its shifting needs". New York Times. 11 March 2004; "Army reserve seeks to toughen up training for parttime soldiers”. National Defense. December 2004.

The whole story was told to me by Cmdt. (later Col.) E van Lill, OC $61 \mathrm{Mech}$, in an e-mail on 16 March 2011. It is borne out by GJJ Oosthuizen. "Regiment Mooirivier and South African transborder operations into Angola during 1975/76 and 1983/84”. Historia 49/1. May 2004. 150, based on on eyewitness accounts.

Notule van nabetragting, Op Askari fase 2, gehou op 27 Januarie 1984 om 10h30, AG saal, Oshakati. <www.61mech.org.za/assets/files/mediafiles/871afe14a3f54ec56d46eb77d5cb 5a8d55911f16_1.pdf>.

F Bridgland. The war for Africa: Twelve months that transformed a continent. Gibraltar: Ashanti, 1990, 321.

E-mail from Col. G Louw, 12 August 2011.

Cf. Bridgland op. cit., pp. 323-333; Heitman, War in Angola ... op. cit.

H Leër/D Opl/G/309/1. Nabetragting Modular/Hooper/Packer, 30 May 1988, Appendix B, paragraph 3 (document provided by R de Vries).

Cf. J Breytenbach: Eagle Strike! The story of the controversial airborne assault on Cassinga 1978. Sandton: Manie Grové, 2008, passim; EG McGill Alexander. "The Cassinga Raid”. MA thesis. Unisa, 2003, passim.

McGill Alexander op. cit., p. 148.

Anon. Gesamentlike militêre aksies deur RSA en UNITA magte teen FAPLA magte in die sesde militêre streek van Angola vanaf Desember 1987 tot Maart 1988.

<www.61mech.org.za/assets/files/mediafiles/a347645f913fffde24b4d14607b0 3059bcbe06cb_1.pdf>. 
Heitman, War in Angola ... op. cit., pp. 326-328. The SAAF also acquired a number of British Tigercat AA missiles from Jordan, but as far as is known, they were never operationally utilised.

Cf. Heitman, Krygstuig van Suid-Afrika, op. cit., p. 91.

Bridgland op. cit., p. 363; Heitman, War in Angola ... op. cit., p. 306.

Heitman, War in Angola ... op. cit., p. 327.

Heitman, Krygstuig van Suid-Afrika op. cit., pp. 92-93.

H Leër/D Opl/G/309/1 op. cit., Appendix E, paragraph 13.

L Scholtz: “The air war over Angola, 1987-1988: An analysis”. Journal for Contemporary History 33/3. February 2009. 258.

SADF: op. cit., Chapter 13, paragraph 176.

Ibid., p. 264.

This is analysed in depth in my forthcoming book.

Scholtz op. cit., p. 251.

South African Airforce. Boeing 707-328C. < www.saairforce.co.za/theairforce/aircraft/13/boeing-707-328c >.

EG McGill Alexander: "South African airborne operations”. Scientia Militaria 31/1. 2003. 58-62.

E-mail from Brig.-Gen. M Alexander, 14 June 2011.

C Bennett. Three frigates: The South African Navy comes of age. Durban: Just Done, 2006, 178.

McGill Alexander, "South African airborne operations" op. cit., p. 81.

Cf. E Jordaan. "An airborne capability for South Africa from a special operations force perspective”. Scientia Militaria 40/1. 2012. 64.

Cf. FJ du T Spies. Angola Operasie Savannah. Pretoria: SAW Direktoraat Openbare Betrekkinge, 1989; S du Preez. Avontuur in Angola: Die verhaal van Suid-Afrika se soldate in Angola 1975-1976. Pretoria: Van Schaik, 1989; P Gleijeses. Conflicting missions: Havana, Washington, Pretoria. Alberton: Galago, 2003.

Breytenbach op. cit., p. 17.

Spies op. cit., p. 259.

Ibid., pp. 304-305.

G. Kruys. "Doctrine development in the South African armed forces up to the 1980s”. In M Hough \& L du Plessis (eds), Selected military issues with specific reference to the Republic of South Africa. Institute for Strategic Studies ad hoc publication no. 38. Pretoria: Institute of Strategic Studies, 13.

This analysis is based on Chapter 12 of my book, as well as L Scholtz. "SuidAfrika se strategiese posisie en die 'Slag van Cuito Cuanavale', 1987-1988” ( to be published in Joernaal vir Eietydse Geskiedenis).

Bridgland op. cit., pp. 32-33.

J Breytenbach. The Buffalo Soldiers: The story of South Africa's 32 Battalion 1975-1993. Alberton: Galago, 2002, 273.

H Leër/D Opl/G/309/1 op. cit., Appendix B, paragraph 4.

Lesse geleer ... op. cit, Chapter 1, Appendix A.

$\mathrm{R}$ Leonhard. The art of maneuver: Maneuver-warfare theory and airland battle. Novato: Presidio, 1991, 115.

Ibid., p. 113. 
Unpublished memoir by R de Vries, in my possession.

PH Frankel. Pretoria's Praetorians: Civil-military relations in South Africa. Cambridge: Cambridge University Press, 1984, 37-44.

McGill Alexander, “The Cassinga Raid” op. cit., p. 142.

J Dippenaar. War diary, Battle Group 61, Operation Sceptic. <http://www.61mech.org.za/assets/files/mediafiles/1a884538192f3052c548afc 9758ebb680ce493dd 1.pdf >.

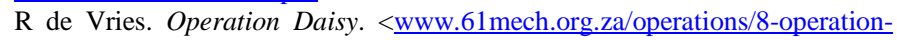
daisy $>$.

Anon op. cit.; e-mail from P Fouché, 3 August 2011.

Anon op. cit., paragraph 525.

Ibid., paragraph 621.

Heitman, War in Angola op. cit., p. 280; Bridgland op. cit., p. 330.

H Leër/D Opl/G/309/1 op. cit., Appendix E, paragraph 1.

E-mail from R de Vries, 10 June 2012.

Lesse geleer ... op. cit, Chapter 1, paragraphs 7-8.

Ibid., Chapter 18, paragraph 6.

Ibid., Chapter 18, paragraph 11.

Ibid., Chapter 18, paragraphs 11 and 9.

See about him: B Bond. Liddell Hart: A study of his military thought. London: Cassell, 1976; A Danchev. Alchemist of war: The life of Basil Liddell Hart. London: Phoenix Giant, 1999.

His best-known work is probably The strategy of the indirect approach (reissued). London: Penguin, 1991.

BH Liddell Hart. Memoirs, I. London: Cassell, 1965, 163.

This is analysed in great detail in my forthcoming book.

Cf. R de Vries. Mobiele oorlogvoering: 'n Perspektief vir Suider-Afrika. Menlopark: FJN Harman, 1987, p. xxii.

$\begin{array}{lllll}\text { Interview with } & \text { C } & \text { Viljoen, } & 26 & \text { July }\end{array}$ <www.nelsonmandela.org/omalley/index.php/site/q/03lv00017/04lv00344/051 v01183/06lv01209.htm>.

I have written an article - now somewhat outdated - about this. Cf. L Scholtz. “Cuito Cuanavale: Wie het werklik gewen?”. Scientia Militaria 28/1. 1998. 16-61. The matter is also analysed in my forthcoming book, but with many more sources.

Quoted by Leonhard op. cit., p. 76.

Quoted by AJ Esterhuyse. "The theories of attrition versus manoeuvre and the levels of war”. Strategic Review for Southern Africa 23/2. November 2002. 88.

PA Crowl. The strategist's short catechism: Six questions without answers. <http://www.au.af.mil/au/awc/awcgate/readings/crowl.pdf $>$.

J Botha. "Suidoos-Angola 1987-89 in persepktief: Castro, Von Clausewitz en Liddell Hart”. In J. Geldenhuys (ed), Ons was daar. Centurion: Kraal Publishers, 2011, 525.

A Seegers. The military in the making of South Africa. London: Tauris, 1996, 141.

Ibid. 
89 WS van der Waals. Potugal's war in Africa. Rivonia: Ashanti, 1993.

90 De Vries, Mobiele oorlogvoering ... op. cit., pp. 174-175.

$91 \quad$ H-R Heitman. “Is the Army literate?”. Militaria 10/1. 1980. 48.

$92 \quad$ A Esterhuyse."Ten years of democracy and the return of bad times: Studying security, strategic and military affairs in South Africa”. Journal for Contemporary History 29/3. 2004. 153-154. 